\title{
Legal Policy on Trade Facilitation Agreements as a Basic for Legal Policy Development
}

\author{
Achmad Ridwan Tentowi ${ }^{1}$ \\ Pasundan University, Bandung, INDONESIA
}

Received 15 April 2019 • Revised 10 June 2019 • Accepted 24 June 2019

\begin{abstract}
Global Competitiveness Report 2016-2017 released data on port competitiveness in Indonesia is ranked $41^{\text {st }}$, come down from previous ranking which was $47^{\text {th }}$. To increase port competitiveness in Indonesia, Indonesia Government ratified Trade Facilitation Agreement (TFA). Context that is claimed in the trade facilitation substantial is the one of the great mainly components on the wheel of Indonesia's economics and the one of economy development key factors (key word) form particular country. This key factor involved the procedure of maintaining the international products progress, thus it would be more efficient. In the field of economic and business, regulation strategy that is related to the trade facilitation is used upcoming port legal politics to increase the capacity of Indonesia in drawing up and implementing the trade facilitation policy.
\end{abstract}

Keywords: port, trade, facilitation, legal politics.

\section{Introduction}

Global Competitiveness Report (Schwab \& Salai-Martín, 2016) studied about the port problems in Indonesia. It revealed that the port competitiveness in Indonesia in in the $41^{\text {st }}$ rank, decrease from the previous position was $47^{\text {th }}$. Indonesia position is lower than Singapore, Malaysia, and Thailand. The weakness of port in Indonesia is the infrastructure and superstructure quality. In 2018, Indonesia is in $45^{\text {th }}$ position out of 140 countries in the Global Competitiveness Index (2018). The index was released by the World Economic Forum (WEF). Previously, Indonesia was ranked $47^{\text {th }}$ in the index. Indonesia recorded an overall score of 64, meaning that Indonesia was superior compared to Mexico in position $46^{\text {th }}$, Philippines $\left(56^{\text {th }}\right)$, India $\left(58^{\text {th }}\right)$, Turkey $\left(61^{\text {st }}\right)$, and Brazil $\left(72^{\text {nd }}\right)$. Nevertheless, Indonesia's competitiveness index lost compared to Malaysia ( $\left.25^{\text {th }}\right)$, Russia $\left(43^{\text {rd }}\right)$, and Thailand $\left(38^{\text {th }}\right)$ (Schwab, 2018).

Regarding the problem against port, it is very crucial, complex and not ease to be identified with certainty, given that development in the port from regulation to business activities always change at any time. Surely, the role of ports is vital in the Indonesian economy, the presence of adequate ports plays a major role in supporting the mobility of products and people in this country (Tentowi, 2016). Ports are the most important factor to connect between islands and

\footnotetext{
${ }^{1}$ Doctor of Law Candidate.
}

(C) Authors. Terms and conditions of Creative Commons Attribution 4.0 International (CC BY 4.0) apply. Correspondence: Achmad Ridwan Tentowi, Pasundan University, Faculty of Law, Bandung, INDONESIA. E-mail: ridwantentowi10@gmail.com. 
countries. However, ironically, the condition of ports in Indonesia is very terrible. Almost all ports in Indonesia are out of date.

Regulation to manage port in Indonesia is very urgent to be recovered immediately, concretely even deconstructing the regulation contained in Law No. 17 of 2008 concerning shipping. The current Government Regulation No. 69 of 2001 is derived from the Shipping Law. The reason why there should be urgent regulation in this port sector is caused by prioritizing regulation that can ensure the element of certainty and fairness will be easily reflected in the port structure.

Through 4.0 industrial revolution, many economy experts who predict that logistic market in 2013 would be the one of the biggest industries in the world, ports in Indonesia has still lower competitiveness than others. It can be happened because the author's observation considered that logistic cost that is still expensive and dwelling time is still high, and it is one of the main causes.

Nowadays, Indonesia is in ASEAN - Economic Community (AEC), (ASEAN Economic Community Blueprint 2025 Jakarta: ASEAN Secretariat, November 2015), thus the improvement of national logistic operational performance must be improved. Collaboration between government and national private sector is an important determinant in construction to build competitiveness of national logistic operational system. Compared to another ASEAN country, Indonesia is relatively low in terms of the logistic competitiveness system. The financial benefits of the ASEAN Economic Community (AEC) 2015 cannot be optimal. Forming commodity price at the consumer level is determined by logistic costs, both product logistics costs and input logistics costs.

The author's observation as businessman in the port has several facts that are in the spotlight of the World Bank worthy of being used as evaluation material in improving the performance of the current and future logistics systems. Henry Sandee stated that logistic cost per 55 kilometers $(\mathrm{Kms})$ in Indonesia is needed around 550 USD, whereas in Malaysia is needed around 300 USD. The cost of shipping one container from Jakarta to Singapore is 185 USD, however the same indicator for shipping Jakarta to Padang costs up to 600 USD. The high logistics costs are not only influenced by the age of the transportation equipment, the factors such as the size of the ship and the condition of the port, but also the factor of the high cost of logistics. Indeed, there are a number of factors that affect logistics, such as ship size and port conditions.

Henry Sandee explained that there are six indicators that can be measured on Logistic Performance Index (LPI). Six indicators are infrastructure conditions, border agency performance, ship availability, and ease of tracking products. Based on survey, Indonesia did not qualify for two of the six factors such as infrastructure condition and performance of the agency at the border. Then, there are further consideration, World Bank released the Logistics Performance Index (LPI) in 2018. This index has a function to measure the country's logistical and economic performance in every 2 years. Meanwhile, components that are measured include customs, infrastructure, international freight forwarding, logistics quality and competency, tracking products, and timeliness.

The port has a very strategic important role for industrial and trade growth as well as business segment that can contribute to national development. This has consequences for the management of the port business segment so that operation can be done effectively, efficiently, and professionally. This can make the port services become smooth, safe, and fast at an affordable cost.

The services that are given to the port are basically the services against ship and service to cargo (products and passengers). The academic point of view sees it as part of the sea transportation chain, the function of port is a meeting place (interface), two modes of transport or 
more and interfaces of various interrelated interests. It can be also said as a line (link) which is one of the links in the process of transportation from the place of origin product to the destination. This will be the gateway (gate), namely as the gateway of a country, where each ship that visits must comply with the rules and procedures that apply in the area where the port is located. The port also functions as an industrial entity, and it means that the port has an important role in the development of the industry of a country/region that is generally oriented to export activities (Putra \& Djalante, 2016).

The author's field observation found that there is unsynchronization or unharmonization between one policy and the others in the port. Therefore, it causes law enforcement to sectoral or partial, legal uncertainty becomes an obstacle. It can make people's welfare is hindered to be able to enjoy the convenience of economic activities. There are many port inefficiencies, inadequate infrastructure, and the absence of logistical laws that will cause high logistical costs. The complexity of the bureaucracy has the effect of reducing the competitiveness of ports in Indonesia. It causes the main vessels to choose ports in Singapore and Malaysia, where the administrative management is more efficient and effective. The absence of a law, especially regulating ports, considering that currently Indonesia has approximately 2,000 ports that are already operating.

Empirical facts prove the gap between reality (das sein) and hope, what aspired is (das sollen), in terms of trade facilitation, such as promoting increased customs and cross-border cooperation between various countries, with the implementation of provisions under the Trade Facilitation Agreement (TFA) of the World Trade Organization (WTO). For instance, the partial implementation of Trade Facilitation Agreement (TFA) can reduce trade costs in the Asia region by up to $5 \%$ every year, whereas implementation completely will result in a $9 \%$ reduction in costs - equivalent to a savings of \$2,019 billion every year (Asian Development Bank, 2017).

In addition, there is also an online delivery order (DO) service, which until now is not suboptimal and been felt by business people. Implementation of online delivery order (DO) is only the movement of products data from shipping to terminal operators which has actually been done for a long time. Currently, the redemption of online delivery orders (DO) to shipping companies runs on a small portion of large shipping companies and has not been integrated in one system. Government efforts to reform and develop the Indonesia port sector are also seen in several Economic Policy Packages (PKE) as accelerated Trade Facilitation Agreement (TFA). This trade facilitation is a member of WTO and it will be very profitable for Indonesia. Indonesia which in fact is a developing country will get trade facilities from other member countries.

\section{Theoretical design}

Trade facilitation (TFA-WTO) nowadays is getting a various places and studies, either economics, politics, law, social, or culture. Through the Law Ratification No. 17 of 2017 concerning Ratification of The Protocol Amending the Marrakesh Agreement Establishing the World Trade Organization (Protocol to Amend the Marrakesh Agreement), finally trade facilitation (TFA-WTO) is legally enforced for Indonesia.

Trade facilitation aims to create conducive system related to products expenditures from the custom area. Thus, trade facilitation agreement is ease of procedure. Article V, VIII, and $\mathrm{X}$ the General Agreement on Tariffs and Trade 1994 concerning Free Transit do not be able yet to be the answer of products transit problems such as the products transit progress is too long, the administrative costs are expensive, and the process of moving products is slow. Article VIII of the General Agreement Tariffs and Trade - 1994 concerning Costs and Import-Export Formality is also not be able yet to be a solution of tariffs and cost problem in the custom area. In regard to the article X of the General Agreement Tariffs and Trade - 1994 concerning Publication and Administration of Trade Policy which are deemed necessary to be regulated further is concerning 
the information disclosure. It is unclear what kind of information can be informed and what type of information cannot be informed. In addition, there is a lack of information about Laws and Regulation changes.

Agreement on Trade Facilitation (TFA) is not claiming about the definition of trade facilitation, either explicitly or implicitly. In essence, trade facilitation is an effort to facilitate the custom procedures, namely transferring, shipping, and licensing of products. WTO only explains that trade facilitation is a simplification and harmonization of international trade procedures, which includes activities, practices, and formalities involved in collecting, presenting, communicating, and processing data required for the products movement in international trade. Electronic Business also confirms trade facilitation as: "The simplification, standardization and harmonization of procedures and associated information flows required to move goods from seller to buyer and to make payment".

International Chamber of Commerce (ICC). According to ICC, the definition of trade facilitation focuses on the improvement of process efficiency related to the comprehensive approach and integrated to simplify and decrease the transaction of international trade cost as well as ensure that all relevant activities is done efficiently, transparently, and predictable, based on the norms that is accepted internationally, on standard, and the best practice. Regarding trade facilitation, there are 4 things that supposed to be as indicator. These four indicators are including: port efficiency; custom area; policy area; and the use of electronic transaction. According to the Organization for Economic Co-operation and Development (OECD), trade facilitation is influenced by some factors, such as:

(1) Availability of information, whether in the form of publishing data through the internet; or other media;

(2) Participation in the trading community;

(3) Advance rulings, namely the provisions for determining the requirements for traders, both regarding classification and product originality;

(4) Appeal procedures mean the process that can be taken to raise the objections to the administrative policies or border officers;

(5) Fees and chargers imposed on export-import activities;

(6) Formality documents is as a form of administrative harmonization requirements based on the international standard;

(7) Formalities-automation: electronic data exchange; automated border procedure; and use of risk management;

(8) Formalities-procedures: streamlining of borders controls (simplification of border controls), one-stop integrated services for submission of all required and authorized economic operators;

(9) Internal cooperation is cooperation between one authority and others in the context of tax system supervision;

(10) External cooperation means the cooperation of state regulation with neighboring countries and third country;

(11) Governance and impartially related to the structure and function of custom.

The provisions in the Trade Facilitation Agreement (TFO-WTO) are in line with the direction of the Welfare State concept. It can be seen from the policy and reformation spirit of Indonesia economy in the field of trade facilitation. Benefits that are expected of the applying of Trade Facilitation Agreement (TFA-WTO) for Indonesia trade in accordance with the concept of Welfare State are as follows:

(1) Smooth and increasing trade in traditional and non-traditional products export markets;

(2) Reduction of logistic and trade cost paid by businessman;

(3) Increasing export for Micro, Small, and Medium Enterprises;

(4) Increasing transparency of export import process. 
Indonesia has improved the port efficiency and customs. But it still necessary to be conducted further improvement. Indonesia's Logistics Performance in accordance with 2014 Logistic Performance Index still lags behind other countries, even with the Southeast Asia region. Various obstacles obstruct thee national logistic condition. Dwelling time at the port is still high which is 3-4 days, while in other countries are only 1 day. Logistic cost that reaches $24 \%$ of the total GDP or Rp1,820 trillion per year makes Indonesia's logistic costs as the highest in the world because the industry is not competitive. Not only about that, but also logistic system that provides convenience for Small and Medium Industries (IKM) and not supported the existence of export commodity exchange. Various burdensome and unclear administrative procedures also contribute to the delays in import and tend to do corrupt behavior which could reduce the competitiveness of industries using imported components.

\section{Discussion}

Port legal politics can be seen by Law No. 172008 about the cruise that port is everything that related to the implementation of port functions to support the smoothness, security, and orderliness of ship, passenger and/or good traffic flow, sailing safety and security, intra and/or intermodal transfer sites as well as encourage the national and regional economy to pay attention toward territorial layout. This legal politics is implemented by Government Regulation (PP) No. 612009 concerning port. The main topic of legal port politics is the smooth flow of products. The main purpose is reducing the dwelling time.

Several things that has already been conducted in the port legal policy including: (1) the Ministry of Transportation has issued Port Operational Service Performance Standards in 100 commercially operate ports, based on Regulation of the Directorate General of Sea Transportation No. HK 103 / 2 / 18 / DJPL - 16 and No. HK 103 / 4 / 7 / DJPL - 16 for 61 ports that have not been commercially cultivated; (2) the working pattern in the port is applied at the Harbor 24/7. The initiation of open port service operation $24 / 7$ is a good thing and should be appreciated, because it has a positive impact on many parties, it can be done because an integrated manner; Port has already been determined online Delivery Order system, this system is implementation of the Minister of Transportation Regulation (Permenhub) No. 1202017 concerning Electronic Order Delivery Service Online (DO). In order to give ship and product services effectively and efficiently, that involved the institutions and stakeholders in the port through an integrated internet-based single service system or Inportnet system. This is in accordance with Permenhub No. 1572015 concerning the Implementation of Inportnet for Ship and Port Services, which has been updated with PM. No. 1922015 concerning Amendment to Permenhub No. 1572015 concerning the Implementation of Inportnet for Ship and Port Services.

There is an implementation weakness of port legal politics today. For instance, 24/7 service has not yet run 100 percent. In this case, not all K/L has operationally fully applied the 24/7 services. For instance, shipping companies through their agencies serving export-import transportation at the port only operate Monday-Friday with operational hours until 16.00 WIB every day. Thus, the activities redemption of delivery order (DO) on shipping time is limited.

This condition is still reasonable because this policy is new and facing many obstacles in the field. Therefore, the improvement and adjustment will be needed in the future. One of factors that influences is the aspect of coordination that has not been in line between the parties involved. It is needed to synergize all related parties simultaneously in the effort of improve them. Besides that, the 24/7 implementation was still hampered by banking activities that were not operating during this time, Inportnet was not yet integrated with INSW, and DO Online was not yet integrated in one line.

Regarding the acceleration of Trade Facilitation Agreement (TFA), the relationship with port legal politics that Trade Facilitation Agreement (TFA), as decreasing or reducing of non- 
tariff barrier. The substances consist of trade transactions, transparency, and professionalism of customs and excise, and the regulatory environment as harmonized with standardization and converted to international provisions or regional provisions.

The main purpose of Trade Facilitation Agreement (TFA) is improving the global trade by expedite the movement, expenditure and licensing of products in and out (movement, release, and clearance of goods), including those in transit (transit). In regard to legal port politics, Trade Facilitation Agreement (TFA) can be used as an effort to regulate the smooth flow of goods in and out of ports in a fast, cheap, and easy way. Hence, the international trade can be increased and price formation occurred profitable for consumers (Suryana, 2016). Trade Facilitation Agreement has 4 indicators. Those are port efficiency; customs environment; policy environment; and the use of electronic transaction equipment.

According to the Organization for Economic Co-operation and Development (OECD), trade facilitation is influenced by several factors, such as (OECD, 2018):

(1) The information either data publication through internet or others;

(2) Trade community participation;

(3) Advance rulings, namely the provisions for determining the requirements for the traders, either classification or product originality;

(4) Appeal procedures that mean the process that can be taken to raise objections to the administrative policies or border officers;

(5) Fees and charges imposed on export-import activities;

(6) Documents-formalities as a form of harmonization of administrative requirements based on the international standard;

(7) Formalities-automation (formalities-automated): electronic data exchange;

(8) Automated border procedure, and use of risk management;

(9) Formalities-procedures (stream formalities): streamlining of borders controls (simplification of border controls), one-stop integrated services for submission of all required documents;

(10) Post-clearance inspection, and authorized economic operators;

(11) Internal cooperation that means the cooperation between one authority and another authority in the context of tax system supervision;

(12) External cooperation that means the cooperation of state regulation with neighboring countries and third countries;

(13) Governance and impartiality related to the structure and function of customs.

Trade facilitation as written on Bali Package Agreement if we associate with port facilitation, then it has been in line with the port policy in Indonesia, for instance trimming costs at the port, simplifying procedures and permits, dwelling time, standardizing port performance, DO online as well as improving and increasing the port facilitation. The main point between port facilitation and trade facilitation can improve the smooth flow of goods and services through the simplification of export-import procedures in the port, as one of efforts to improve competitiveness.

The explanation above can influence the flow of international trade. Trade facilitation also includes transportation cost that can be seen from the distance factor between exporter and importer countries as well as supporting infrastructure. In December 2013 WTO conducted the negotiation agreement about trade facilitation that was discussed about the obstacle that still can be found such as type of documents, procedure on trade partner country borders, and customs 
fee. This is focused on completing the producers that are considered complicated which hamper export and import activities between countries.

As a basic explanation above, Trade Facilitation Agreement (TFA-WTO) with port facilitation can be seen as the relationship between politics and law. As same as justice perspective theory that reanalyze the basic problem based on politics philosophical study by reconciling between the principle of freedom and the principle of equality. Surely, there is similarity principle between countries which ratifies it in the trade facilitation. Hence, quality principle before the law can be used as a reference to obey the trade facilitation as an improvement to port facilitation.

Another context claimed that the more prosperous civilization, the more economics justice based on the purpose of law, so the law will be easier to be updated (law reform). It means that the harbor is healthy, providing many opportunities for justice, then the establishment of maritime law will be easily realized.

While legal order is conceptualized as only a subsystem that supposed to be functional in a supersystem that is called society (port society), so the development process and development of society to realization of a new political society (port politics) absolutely on efforts to re-function the law as institution that should be considered strategic in social-politics. Legislation process emphasizes on the process of new national port law realization. The process of integrating the law for realization the new law without being denied is part of a progressive and reformative political process.

Port and trade facilitation are tools, so legal order that would be formed can be functioned as a tool of social engineering whether it is activated by judicial processes (as Roschoe Pound claimed) or by legislative processes (as introduced by Mochtar Kusumaatmadja for Indonesia development practice) (Kusumaatmadja, 1976).

The reformative function which is as a tool of engineering often still discussed in its limited concept as legal reform in Indonesia. It means that port legal politics is limited to legal reform or renewal of the act. It must literally be interpreted as a renewal in the system of mere legislation. The answer of this problem is very clear, which is in the renewal of the updated law.

Legal politics surely has important meaning because every law that was created, every law that was applied in the society, should be acceptable in the society. It is supposed to rule by the right law (Karim, 2013). Legal politics is used to reveal the changes that is necessary to be issued to the law to fulfill the new needs in the society. As the theoretical foundation in Chapter II, the author uses Political Theory of Law. It can be applied in legal politics of renewal of Law No. 21 1992 towards Law No. 172008 concerning shipping.

Legal politics manifested in the kind of living together with society. In other words, legal politics are closely even almost integrated (integrated, systematic) with the use of power in reality (social and legal reality), to regulate the state, nation, and people. Political law is manifested in all types of state legislation. The use of this legal political discourse is actually to support the mandate and ideals as set out in the 1945 Constitution Article 33. This context shows that the economic constitution in substance Article 331945 Constitution was born from the socio-context historical independence revolution. Economic decolonization from the colonial to the national constitutes the legal politics paradigm of economic Constitutional Law Article 331945 Constitution.

This paradigm makes countries to be active in the economics. It is same as the prosperous country concept that is written on economy Constitution Article 331945 has changed in the reformation era, which initiated a fundamental shift in the direction of the Indonesia economy towards economic reform by incorporating the paradigm of liberalism in the constitution. 
Political Law No. 172008 concerning shipping which regulates port issues is stipulated in Government Regulation (PP) No. 612009 concerning port. According to the author has explained in Chapter II that legal politics as stated in Law No. 172008 concerning shipping can be found in the consideration as follows:

(1) The Unitary State of the Republic of Indonesia (NKRI) is an archipelago that is characterized by an archipelago united by vast territorial waters with boundaries, rights, and sovereignty stipulated by the Law.

(2) To achieve national goals based on Pancasila and 1945 Constitution of the Republic of Indonesia, realizing the archipelago's insight and strengthening national security, a national transportation system is needed to support economic growth, regional development, and strengthen national sovereignty.

(3) Shipping which consists of transportation in the sea, port, safety and security of shipping, and protection of the maritime environment is part of the national transportation system that has to be developed for its potential and role to realize an effective and efficient transportation system, and to help create a national distribution pattern steady and dynamic.

(4) The development of national and international strategic environment demands the implementation of shipping in accordance with the development of science and technology, private participation and business competition, regional autonomy, and accountability of state administrators, while prioritizing shipping safety and security in the national interest.

Political Law that is contained in point No. 3 above, that the discussion on port needs to be specifically regulated is as contained in Government Regulation (PP) No. 61 of 2009 concerning Port. In the legal political substance of the Shipping Law, it implies that the Port / PT. Pelindo, as a State-Owned Enterprise (BUMN), as well as a Port Business Entity (BUP), is under the authority of the Port Authority (OP) as an authority that carries out control, regulation and supervision. However, in the reality of legal life in the port this is not progressively done, there is something called the polemic of interest, pulling withdrawing authority and banging lower rules on the authority given by the act.

The existence of law in every area of daily life, both the steps taken, decided or the policies of the Government must be suitable with the values that live in the community (the living law). The concept of law can be interpreted as lines of legal policy formed by a legal society. This contains a sign that the law must be rooted in and for the community (David Nelken, Eugen Ehrlich, Living Law, and Plural Legalities). Determination of this concept is an initial stage that is very important for the process of forming, implementing, and developing the law of a society. Its importance lies in the potential possessed by a legal concept, which in turn is the basis and orientation for a legal implementation and development process.

The purpose of establishing (positive) law is fulfilling the basic needs of the whole community and as a legal social tool clearly serves, as a guiding principle, as a means to safeguard people's needs and as a social control system. According to Kusumaatmadja (2006), it was explained that he law has a dimension to support national development through legislation specifically designed to mobilize development by mobilizing and motivating people as actors of development, including relevant government apparatus.

Law in this context means that community reforms (law reform society), which is based on the assumption that the existence of order in the business of development and renewal is a desired or deemed necessary. Another assumption that is contained in the legal conception which means of renewal is that law in terms of rules or legal rules can indeed function as a tool (regulator/regulation) or means of development in the sense of channeling the direction of human activity in the direction desired by development and renewal. 
Through the legal paradigm, both sociological, philosophical and positivism (legist), of course justice, order is the main purpose, while the development of law is the impact of achieving the objectives of the law. All the objectives of the law are reflected in each of the joints of life, in this case, the author has not seen the points that the purpose of the law can be achieved carefully. Why has not been achieved, one example of which is a legal goal that is not achieved in Law No. 17 of 2008 concerning shipping.

\section{Conclusion}

Substantial that is written on the port legal politics can be reflected in the Law ratification No. 17 of 2008 about cruise. Legal politics is supported by any devices such as: Port Operational Service Performance Standard in 100 commercially-operated ports; 24 hours sevenday week-long work program (24/7 program) is implemented, and the online Delivery Order (DO) system has been implemented as well as internet-based single service system is integrated or the Inportnet system. After that, The International Security Code is applied at the port to ships and port facilities (the International Ship and Port Facility Security Port - ISPS Code). This political legal device has function to support the 4.01 industrial revolution in the port. Related to the acceleration of trade facilitation agreement based on justice, it is the same as 1945 Constitution in Article 33 (verse 1, 2, 3, 4) and Law No. 17 2008. Justice and certainty legal value is reflected in simplification, transparency, standardization, harmonization of procedures, and international trade documents that must be supported by the smooth flow of products and port efficiency under the coordination of the Port Authority (OP).

\section{Acknowledgements}

This research did not receive any specific grant from funding agencies in the public commercial, or not-for-profit sectors.

The author declares no competing interests.

\section{References}

Abd Rahman, A., Jamali, J. \& Wong, H.W. (2006). The maritime sector and the Malaysian economy. Kuala Lumpur: MIMA.

ASEAN Economic Community Blueprint 2025 (2015). Jakarta: ASEAN Secretariat, November 2015.

Asian Development Bank (2017). Fasilitasi Perdagangan Yang Lebih Baik Dapat Kurangi Biaya Perdagangan di Asia Hingga $9 \%$ per Tahun - Laporan [Better trade facilitation can reduce trade costs in Asia up to 9\% per year - Report]. Retrieved 5 September 2017, from

https://www.adb.org/id/news/better-trade-facilitation-could-reduce-trade-costsasia-9-annually-report

... (2014). Harianto, Paket Bali WTO dan Relevansinya bagi Pertanian Indonesia [Harianto, Bali WTO package and its relevance to Indonesian agriculture]. Retrieved 18 August 2014, from http://www.setkab.go.id/artikel-11423-paket-bali-wto-dan-relevansinya-bagipertanianindonesia.html. 
A. R. Tentowi - Legal Policy of Trade Facilitation Agreements...

Kusumaatmadja, M. (1976). Hukum, Masyarakat, dan Pembinaan Hukum Nasional [Law, society, and national law development]. Bandung: Lembaga Penelitian Hukum dan Kriminologi Fakultas Hukum Universitas Padjajaran.

Kusumaatmadja, M. (2006). Konsep-konsep hukum dalam pembangunan [Legal concepts in development]. Bandung: Alumni.

Karim J. (2013). Politik Hukum Legalistik [Politics of legalistic law]. Yogyakarta: Imperium.

Labaratorium Mini Pemangku Kepentingan. (2014). Sosialisasi Inisiatif Charter Optimalisasi Pelayanman 24 / 7. Jakarta: Tanjung Priok.

Lasse, D. A. (2011). Manajemen Kepelabuhanan [Port management]. Jakarta: PT. Raja Grafindo Persada.

Nelken, D. (2008). Eugen Ehrlich, living law, and plural legalities. Theoretical Inquiries in Law, 9, 443-471.

OECD (2018). OECD Trade Facilitation Indicators-Indonesia, the Organisation for Economic Co-operation and Development. Retrieved 27 August 2018, from

http://www.oecd.org/tad/facilitation/indonesia-oecd-trade-facilitation-indicatorsapril-2014.pdf.

Putra A. A., \& Djalante S. (2016). Pengembangan Infrastruktur Pelabuhan Dalam Mendukung Pembangunan Berkelanjutan [Port infrastructure development in supporting sustainable development]. Jurnal Ilmiah Media Engineering, 6(1), 433-4.

Rasjidi, L. \& Putra, I.B. Wyasa (2003). Hukum Sebagai Suatu Sistem [Law as a system]. Bandung: Mandar Maju.

Schwab, K. (2018). The global competitiveness report 2018. Geneva: World Economic Forum.

Schwab, K., \& Salai-Martín, X. (2016). The global competitiveness report 2016-2017. Geneva: World Economic Forum.

Suryana, A. (ed.) (2016). Fasilitasi perdagangan: kesiapan Indonesia menghadapi persaingan global [Trade facilitation: Indonesia's readiness to face global competition]. Jakarta: Pusat Penelitian Badan Keahlian DPR RI dan PT Balai Pustaka (Persero).

Tentowi, A. R. et al. (2016). Politik hukum tata kelola kepelabuhanan nasional: Studi Kasus Dwelling Time di Tanjung Priok [The politics of national port governance law: A case study of Dwelling Time in Tanjung Priok]. Bandung: CV. Warta Bagja.

Unctad, (1982). General cargo operation management. Candiff: Drake Educational Associates.

Wilson, J. S., Mann, C. L. \& Otsuki, T. (2003). Trade facilitation and economic development: a new approach to quantifying the impact. The World Bank Economic Review, 17(3), 367-389.

Wilson, J. S., Mann, C. L. \& Otsuki, T. (2005). Assessing the potential benefit of trade facilitation: a global perspective. In: P. Dee \& M. Ferrantino (Eds.), Quantitative methods for assessing the effects of non-tariff measures and trade facilitation (pp. 121-160). World Bank policy research Working Paper No. 322. 